\title{
RUNOFF AND SEDIMENT YIELD VARIATIONS UNDER DIFFERENT PRECIPITATION CONDITION AND LAND-USE TYPE: A CASE STUDY OF FANGXI WATERSHED IN THE POYANG LAKE BASIN, CHINA
}

\author{
TonG, X. X. ${ }^{1,2}-$ ZHOU, Y. C. ${ }^{*}-$ Xu, W. S. ${ }^{1,2}-$ DONG, L. Y. ${ }^{1,2}$ \\ ${ }^{I}$ Changjiang River Scientific Research Institute of Changjiang Water Resources Commission, \\ Wuhan, Hubei 430010, China \\ ${ }^{2}$ Research Center on Mountain Torrents and Geological Disaster Prevention, Ministry of Water \\ Resources, Wuhan, Hubei 430010, China \\ (phone: +86-027-8292-6559; fax: +86-027-8292-6357) \\ *Corresponding author \\ e-mail: zhouyc_omg@126.com; phone: +86-027-8292-7551; fax: +86-027-8292-6357 \\ (Received 23 ${ }^{\text {rd }}$ Aug 2019; accepted $15^{\text {th }}$ Nov 2019)
}

\begin{abstract}
A research was conducted on runoff and sediment yield variations under different precipitation and land-use conditions was performed based on the Soil and Water Assessment Too1 (SWAT) model using China Meteorological Assimilation Driving Datasets (CMADS). The observation data was collected in the Fangxi Lake Watershed, a typical irrigation district in the Poyang Lake basin of China. The results indicated a positive correlation between annual runoff and precipitation, as well as between annual sediment yield and precipitation. The correlation coefficient of annual runoff yield and precipitation was 0.94 , whereas that of annual sediment yield and precipitation was 0.85 . The monthly yield of runoff and sediment of a typical year (2004) was simulated. The runoff and sediment yields had the same tendency of changes with precipitation variations. Differences were found among the per unit area yield of total runoff from different land-use types in 2004. The order from highest to lowest was paddy land $>$ rural residential land $>$ dry land $>$ water area. For the per unit area yield of total sediment from different land-use types, the order from highest to lowest was rural residential land $>$ dry land > water area > paddy land. The results of this study might provide guidance for soil erosion control in irrigation districts.
\end{abstract}

Keywords: land-use, precipitation, runoff and sediment yield, SWAT model, CMADS

\section{Introduction}

The Soil and Water Assessment Too1 (SWAT) model is one of the distributed hydrological models. It is a physically based model developed by the Blackland Research and Extension Center and the United States Department of Agriculture Agricultural Research Service to predict the effect of land management practices on water, sediment, and agricultural chemical yields in large, complex basins with varying soil types, land use, and management conditions over long periods of time (Gassman et al., 2007). The SWAT model can respond to the changes in land use, weather, topography, and soil data. The effectiveness and applicability of this model has been validated by numerous studies worldwide (Binh et al., 2011; Daggupati et al., 2018; Hao and Cheng, 2006; Himanshu et al., 2017; Koua et al., 2013; Lam et al., 2010; Loliyana and Patel, 2018; Santhi et al., 2006; Zettam et al., 2017).

Runoff and sediment simulation is one of the most basic and important functions of SWAT model. The SWAT model has been improved by numerous investigators by combining it with the local watershed. Some researchers demonstrated the applicability 
of SWAT model for runoff and sediment simulation under different temporal and spatial scales and different hydrogeological conditions in the Mississippi River basin and other river basins in the United States (Arnold et al., 1999; Green and Griensven, 2008). Several studies analyzed different aspects of SWAT model simulation, such as the correlation between runoff and precipitation and the impact of land use on sediment and non-point source pollution in other countries and districts (Bärlund and Kirkkala, 2008; Di Luzio et al., 2005; Lee and Kim, 2017; Min and Shibata, 2016; Panagopoulos et al., 2011; Weber et al., 2001).

Most of the studies were based on a natural watershed. However, huge differences were found between irrigation district and natural watershed on account of intensive human activities on land cover and hydrological cycle system in irrigation districts. The SWAT model has been improved with the practical situation of irrigation district to enhance the simulation accuracy. Some researchers (Dai and Cui, 2009a, b; Dechmi et al., 2012; Li et al., 2014) improved the SWAT model based on specific irrigated watershed considering the water cycle in paddy land, irrigation, and drainage management, and other irrigation channel management actions. The results indicated that the improved SWAT model could show more accurate and better simulation performance than the original SWAT model.

Although the SWAT model has been widely used across the world, it is difficult to apply in areas where meteorological data are scarce (Meng et al., 2018). Therefore, the meteorological data is needed for runoff and sediment simulation in a watershed with scarce data (Meng et al., 2016). The China Meteorological Assimilation Driving Datasets for the SWAT model was developed by Meng from the China Institute of Water Resources and Hydropower Research (IWHR). It covers the entire East Asian region between 2008 and 2014 (Meng and Wang, 2017). Some studies demonstrated that the SWAT model yielded better results for runoff simulation with CMADS (Liu et al., 2017, 2018). Meng et al. also used three different datasets to simulate runoff in the Heihe basin, and the results indicated that the simulation accuracy of the CMADS was higher than that of other datasets (Meng et al., 2016).

The SWAT model and CMADS data were used in the present study to simulate the runoff and sediment yield under different precipitation and land-use conditions in the study area, a small irrigated plain district of Poyang Lake region. The correlation between runoff and precipitation, as well as between sediment and precipitation, was investigated. In addition, the diversities of runoff yield and sediment yield from different land-use types were simulated and analyzed. The results obtained in this study might provide guidance for soil and water conservation and land-use management of the study area as well as other irrigation districts of Poyang Lake region.

\section{Materials and methods}

\section{Study area}

The Fangxi Lake Watershed is located in the southwestern region of Poyang Lake basin, which is in the southeastern of China, between $116^{\circ} 0^{\prime} \mathrm{E}$ and $116^{\circ} 5^{\prime} \mathrm{E}$ and between $28^{\circ} 29^{\prime} \mathrm{N}$ and $28^{\circ} 33^{\prime} \mathrm{N}$, covering an area of 3080.20 ha (Fig. 1). The Fangxi Lake Watershed features a subtropical monsoon climate and has four distinct seasons, where summers are warm with abundant precipitation whereas winters are cold and dry with little precipitation. The multi-year average precipitation is $1624.4 \mathrm{~mm}$ per year, and the annual rainy days are about 147.3 days. The annual average temperature is $17.6^{\circ} \mathrm{C}$. 
The main soil type in this watershed is paddy clayey soil, which occupies $90.69 \%$ of the total area. It includes three subclasses: yellow clayey soil (76.52\%), lake clayey soil $(12.38 \%)$, and sand clayey soil $(1.79 \%)$. The main land-use types in the study area are paddy land $(79.27 \%)$, water area $(12.63 \%)$, rural residential land $(6.11 \%)$, dry land $(1.71 \%)$, forest and grass land $(0.24 \%)$, and bare land $(0.04 \%)$. The main crop is rice and the double-cropping paddy area occupies approximately $95 \%$ of the total cultivated area. Other crops include watermelon, muskmelon, garlic, and fragrant-flowered garlic.

The area has 17,404 permanent residents, and the main types of livestock and poultry industry are ducks, chickens, pigs, cattle, and sheep. Aquaculture is highly developed because of its abundant water resources in this area. The aquaculture area occupies $30 \%$ of the water area.

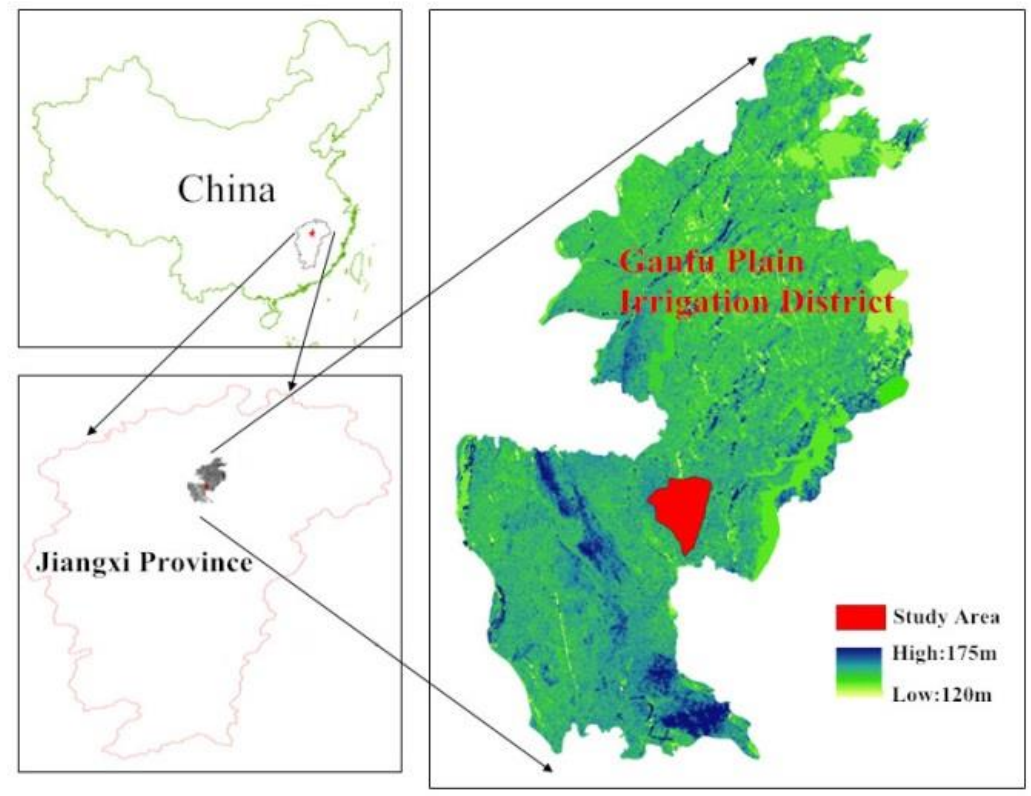

Figure 1. Location of the study area

\section{Data collection}

The distributed model based on the SWAT model requires spatial and attribute data. Furthermore, the spatial data includes digital elevation model (DEM), water distribution map, and land-use and soil maps. The attribute data includes the physical and chemical properties of soil, meteorological and hydrological information (including rainfall, temperature, wind speed, relative humidity, and net solar radiation.), observed runoff, and farmland management measures. The sources and main types of data collected are shown in Table 1. The DEM, land-use map, and soil maps are shown in Figure 2a-c.

The simulation accuracy of SWAT model depends largely on the description of the watershed characteristics of the input data. For runoff and sediment simulation, highprecision meteorological data can accurately describe the meteorological characteristics of the watershed and lead to better simulation results (Chen et al., 2016). Only one precipitation station exists near the study area. The China Meteorological Assimilation Driving Datasets for the SWAT model version 1.1 (CMADS V1.1) was introduced in this study to get the entire meteorological data for the study area. The climate data used in this study were downloaded from the official website (http://www.cmads.org). 


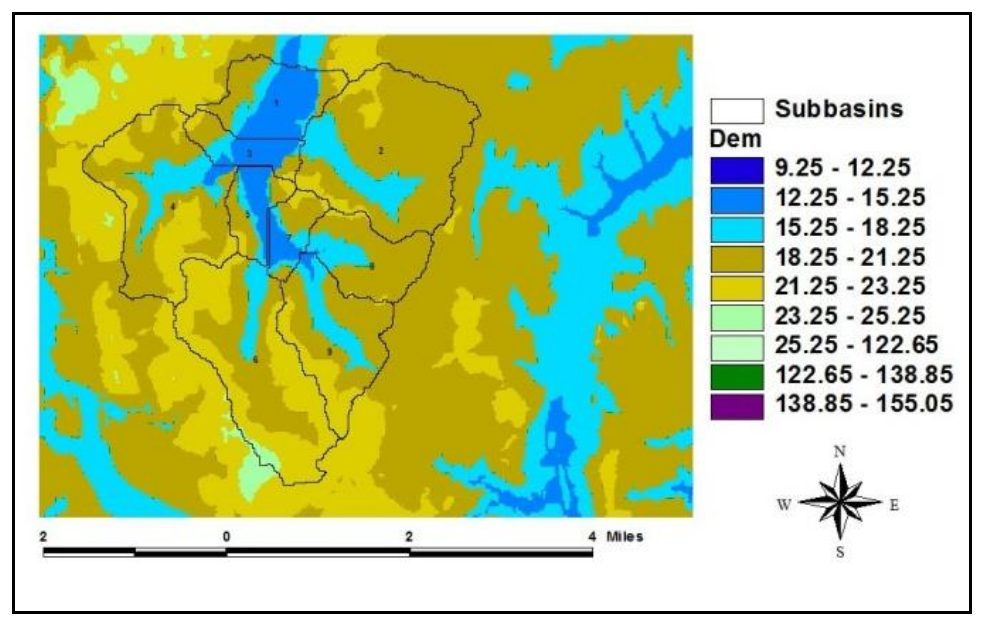

Figure 2a. DEM of the study area

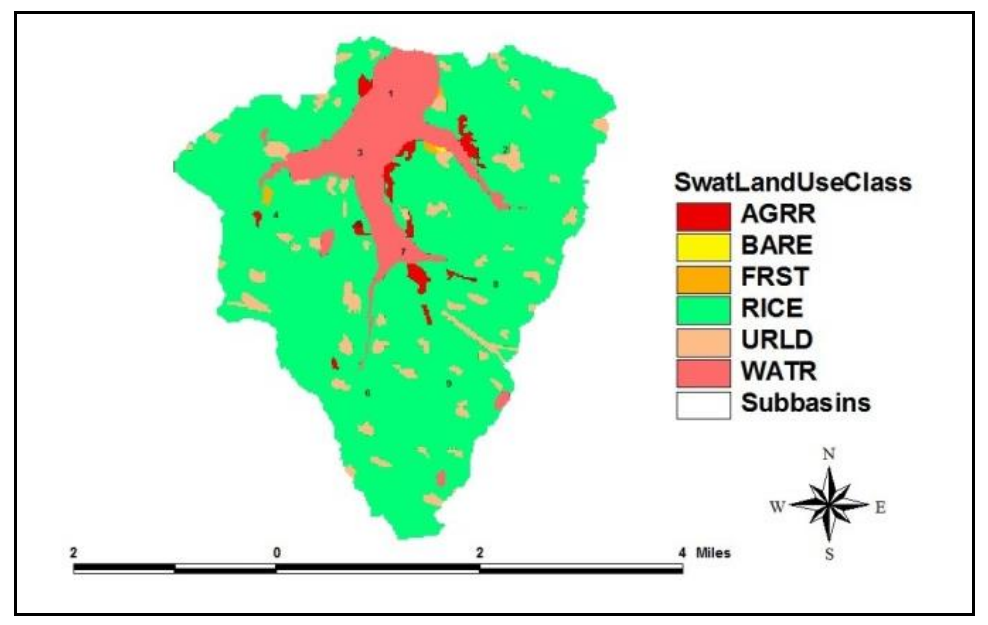

Figure 2b. Land-use map of the study area (AGRR is dry land, BARE is bare land, FRST is forest and grass land, RICE is paddy land, URLD is rural residential land, and WATR is water area)

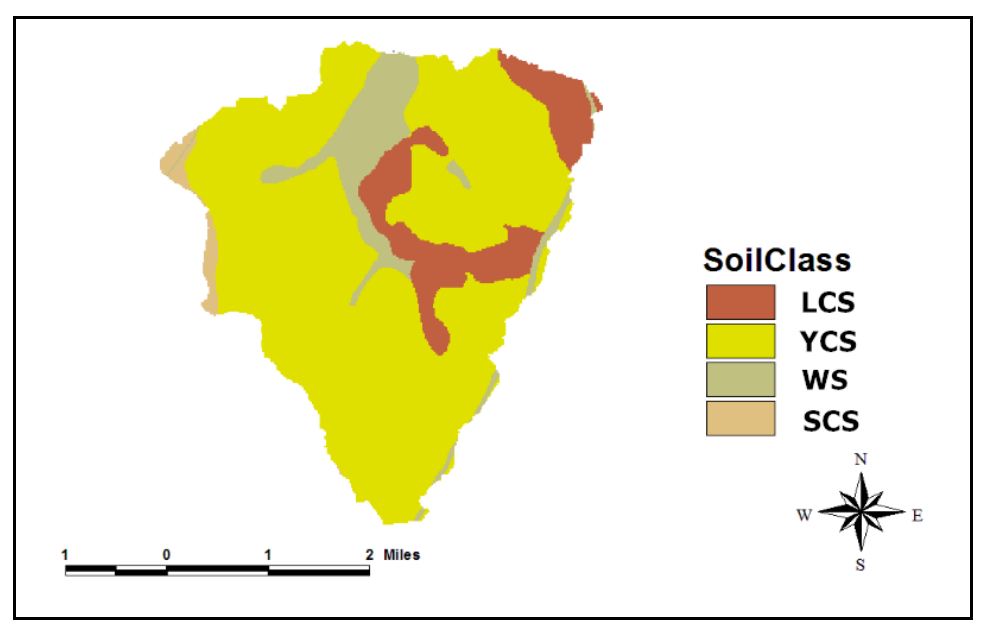

Figure 2c. Soil map of the study area (LCS is lake clayey soil, YCS is yellow clayey soil, WS is water surface, and SCS is sand clayey soil) 


$$
-15673 \text { - }
$$

Table 1. Sources and types of data collected for the SWAT model

\begin{tabular}{|c|c|c|c|c|}
\hline No. & & Data type & $\begin{array}{c}\text { Temporal/spatial } \\
\text { resolution }\end{array}$ & Source \\
\hline 1 & \multirow{4}{*}{ 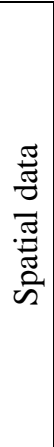 } & $\begin{array}{c}\text { Digital elevation } \\
\text { model (DEM), } 25 \mathrm{~m}\end{array}$ & Grid format, $30 \mathrm{~m} /$ grid & $\begin{array}{l}\text { Geospatial Data Cloud of China } \\
\text { (http://www.gscloud.cn/) }\end{array}$ \\
\hline 2 & & Water distribution map & Shape format & $\begin{array}{c}\text { Drawn by the authors of this manuscript } \\
\text { based on the water distribution of the study } \\
\text { area }\end{array}$ \\
\hline 3 & & Soil map & $\begin{array}{c}\text { At the scale of } 1: 100,000 \\
\text { compiled in } 2009\end{array}$ & Nanchang County Agricultural Bureau \\
\hline 4 & & Land-use map & $\begin{array}{c}\text { At the scale of } 1: 100,000 \\
\text { compiled in } 2009\end{array}$ & $\begin{array}{c}\text { Computer Network Information Center of } \\
\text { Chinese Academy of Science } \\
\text { (http://www.cnic.cas.cn) }\end{array}$ \\
\hline 5 & \multirow{3}{*}{ 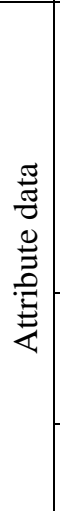 } & $\begin{array}{l}\text { Meteorological data, } \\
\text { daily }\end{array}$ & Daily data & $\begin{array}{l}\text { China Meteorological Assimilation Driving } \\
\text { Datasets for the SWAT Model (CMADS) } \\
\text { (calculated temperature, solar, wind data } \\
\text { between } 2008 \text { and 2014), Jiangxi Irrigation } \\
\text { Experimental Center (observed } \\
\text { precipitation data between January 1, } 1978 \\
\text { and November 30, 2011) }\end{array}$ \\
\hline 6 & & Hydrological data & Daily runoff yield & $\begin{array}{c}\text { Jiangxi Irrigation Experimental Center } \\
\text { (observed data between May to October in } \\
\text { 2011) }\end{array}$ \\
\hline 7 & & $\begin{array}{c}\text { Farmland management } \\
\text { measures }\end{array}$ & $\begin{array}{l}\text { Daily data during crop } \\
\text { growth period }\end{array}$ & $\begin{array}{l}\text { Field investigation based on the study area } \\
\text { (observed data in 2011) }\end{array}$ \\
\hline
\end{tabular}

The farmland management measures are also important information for runoff and sediment yield research in the study area. Double-cropping rice is cultivated in most of the study area. The growing period of early rice is April to July and that of late rice is July to October. Irrigation and drainage measures of double-cropping rice are gained by farm surveys. The surveyed data are shown in Table 2.

Table 2. Irrigation and drainage measures

\begin{tabular}{c|c|c}
\hline & Date & Measures \\
\hline \multirow{3}{*}{ Early rice } & April 14 & Irrigation, $50 \mathrm{~mm}$ \\
& April 23 & Irrigation, $50 \mathrm{~mm}$ \\
May 18 & Drainage \\
May 22 & Irrigation, $50 \mathrm{~mm}$ \\
& July 6 & Drainage \\
\hline \multirow{2}{*}{ Late rice } & July 18 & Irrigation, $50 \mathrm{~mm}$ \\
& July 26 & Irrigation, $50 \mathrm{~mm}$ \\
& July 31 & Irrigation, $50 \mathrm{~mm}$ \\
& August 7 & Irrigation, $50 \mathrm{~mm}$ \\
& August 19 & Drainage \\
& September 3 & Irrigation, $50 \mathrm{~mm}$ \\
& September 21 & Irrigation, $50 \mathrm{~mm}$ \\
& October 31 & Drainage \\
\hline
\end{tabular}

All data were prepared for the model setup 


\section{SWAT model setup}

\section{Model construction}

In this study, the spatial data in Table 1 were loaded into the SWAT model, and the distributed hydrological model based on the study area was constructed. Nine subbasins were calculated based on the DEM and river network distribution of the study area, and then 51 hydrological response units (HRUs) were subdivided based on the spatial distribution of the land-use type, soil type, and slope. The results are shown in Figure 3 and Table 3.

The meteorological data were loaded into the SWAT model after HRU subdivision. Then, a distributed hydrological model based on the SWAT model was constructed in the study area.

Table 3. Area of sub-basins and HRUs in the study area

\begin{tabular}{c|c|c|c}
\hline Sub-basins & Number of HRUs & Area (ha) & Area percentage (\%) \\
\hline 1 & 4 & 253.59 & 8.23 \\
2 & 8 & 685.23 & 22.25 \\
3 & 6 & 122.63 & 3.98 \\
4 & 6 & 571.78 & 18.56 \\
5 & 7 & 127.43 & 4.14 \\
6 & 2 & 623.55 & 20.24 \\
7 & 10 & 105.14 & 3.41 \\
8 & 5 & 232.73 & 7.56 \\
9 & 3 & 358.12 & 11.63 \\
\hline Total & $\mathbf{5 1}$ & $\mathbf{3 0 8 0 . 2 0}$ & $\mathbf{1 0 0}$ \\
\hline
\end{tabular}

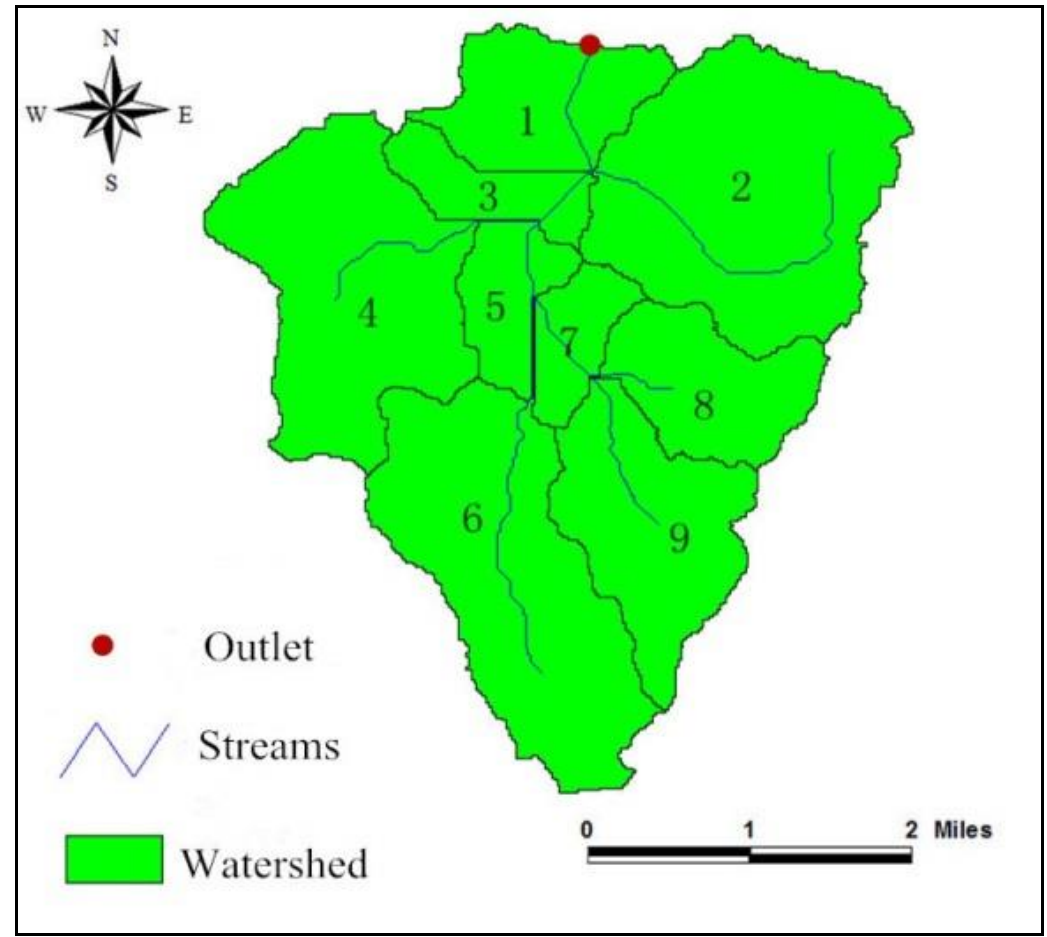

Figure 3. Sub-basins of the study area 


$$
-15675 \text { - }
$$

\section{Model calibration and evaluation}

Model calibration was based on the optimization of the parameter values by adjusting the simulated runoff and sediment yield data at the outlet of the basin with observed data. That is to say, the parameters of runoff and sediment yield in the SWAT model were adjusted to a reasonable range to get accurate simulation results in this study.

Some parameters called sensitive parameters can have an evident impact on the results of model simulation. These parameters were adjusted to a reasonable value for better simulation results. On the basis of some studies on the sensitivity analysis of SWAT model (Me et al., 2015; Yang et al., 2013), the main sensitive parameters of runoff and sediment yield adjusted in this study are shown in Table 4.

Table 4. Main parameters of runoff and sediment yield in the SWAT model

\begin{tabular}{c|c|c}
\hline & Parameter & Description \\
\hline \multirow{5}{*}{ Runoff parameter } & CN $_{2}$ & SCS runoff curve calculating parameter \\
& ESCO & Soil evaporation compensation coefficient \\
& SOL-AWC & Crop transpiration compensation coefficient \\
& REVAPMN & Soil available water capacity \\
& GW-REVAP & Water table threshold for shallow groundwater re-evaporation \\
& GWQMN & Groundwater re-evaporation coefficient \\
& USLE_C & Runoff coefficient of shallow groundwater \\
\hline \multirow{5}{*}{ Sediment parameter } & USLE_P & Minimum value of vegetation coverage factor \\
& USLE_K & Soil and water conservation factor of USLE equation \\
& CH_CROD & Soil erosion coefficient of USLE equation \\
& SPCON & Channel scour coefficient \\
& SPEXP & Channel coverage coefficient \\
\hline
\end{tabular}

The relative error $\left(R_{e}\right)$, correlation coefficient $\left(R^{2}\right)$, and Nash-Sutcliffe efficiency (Ens) were used to evaluate the model performance. The formulas used for calculating these indexes are as follows:

$$
\begin{gathered}
R_{\theta}=\frac{Q_{p}-Q_{0}}{Q_{0}} \times 100 \% \\
R^{2}=\left[\frac{\sum_{i=1}^{n}\left(Q_{0}-\overline{Q_{0}}\right)\left(Q_{p}-\overline{Q_{p}}\right)}{\sqrt{\sum_{i=1}^{n}\left(Q_{0}-\overline{Q_{0}}\right)^{2} \sum_{i=1}^{n}\left(Q_{P}-\overline{Q_{p}}\right)^{2}}}\right]^{2} \\
\text { Ens }=1-\frac{\sum_{i=1}^{n}\left(Q_{0}-Q_{P}\right)^{2}}{\sum_{i=1}^{n}\left(Q_{0}-\overline{Q_{0}}\right)^{2}}
\end{gathered}
$$

where $Q_{p}$ is the simulation value, $\overline{Q_{p}}$ is the average simulation value, $Q_{0}$ is the observed value, $\bar{Q}_{0}$ is the average observed value, and $n$ is the number of observed data. The 


$$
-15676 \text { - }
$$

evaluation standard indexes of model simulation efficiency are shown in Table 5. Generally, the model performances are identified to be good enough to apply in actual numerical simulation if $\mathrm{R}_{e}<10 \%, \mathrm{R}^{2}>0.79$, and Ens $>0.59$.

Table 5. Evaluation standard of model simulation efficiency

\begin{tabular}{c|c|c|c}
\hline Standard & $\begin{array}{c}\text { Relative error } \\
\left(\boldsymbol{R}_{\boldsymbol{\theta}}, \boldsymbol{\%}\right)\end{array}$ & $\begin{array}{c}\text { Correlation coefficient } \\
\left(\boldsymbol{R}^{\mathbf{2}}\right)\end{array}$ & $\begin{array}{c}\text { Nash-Sutcliffe efficiency } \\
(\text { Ens })\end{array}$ \\
\hline Excellent & -5 to +5 & $1.00-0.95$ & $1.00-0.80$ \\
Good & \pm 5 to \pm 10 & $0.94-0.80$ & $0.79-0.60$ \\
Medium & \pm 10 to \pm 20 & $0.79-0.70$ & $0.59-0.40$ \\
Awful & $>20$ or $<-20$ & $<0.70$ & $<0.40$ \\
\hline
\end{tabular}

For runoff parameters, the observed runoff data at the outlet of the study area from May to October 2011 were used for model calibration and evaluation. Especially, the meteorological data of CMADS were used for model simulation to increase the accuracy of model simulation. In addition, the daily runoff data during the period 20082011 were simulated, choosing 2008-2010 as the warm-up period of SWAT model simulation. Some studies showed that the warm-up could make better simulation results for SWAT model simulation (Li et al., 2013; Nyeko, 2015; Wang et al., 2017, 2015). Figure 4 shows the comparisons between the observed and simulated runoff yield of the study area outlet during the model calibration and validation period. Table 6 shows the performance of SWAT model during the calibration and validation periods. The optimum values of the calibrated runoff parameters are shown in Table 7.

Table 6. Evaluation standard of model simulation efficiency

\begin{tabular}{c|c|c|c}
\hline & $\boldsymbol{R e}(\boldsymbol{\%})$ & $\boldsymbol{R}^{\mathbf{2}}$ & $\boldsymbol{E n s}$ \\
\hline Calibration period & 15.5 & 0.88 & 0.74 \\
Validation period & 12.4 & 0.90 & 0.78 \\
\hline
\end{tabular}

Table 7. Optimum value of calibrated runoff parameters for the SWAT model

\begin{tabular}{c|c|c|c|c|c}
\hline Name & Paddy land & Dry land & Rural residential land & Bare land & Grass land \\
\hline CN2 & 70 & 85 & 86 & 90 & 78 \\
ESCO & 0.3 & 0.6 & 0.7 & 0.5 & 0.5 \\
EPCO & 0.7 & 0.8 & 0.5 & 0.5 & 0.8 \\
SOL-AWC & 0.18 & 0.13 & 0.14 & 0.16 & 0.18 \\
REVAPMN & 450 & 450 & 450 & 450 & 450 \\
GW-REVAP & 0.2 & 0.2 & 0.2 & 0.2 & 0.2 \\
GWQMN & 1 & 1 & 1 & 1 & 1 \\
\hline
\end{tabular}

For sediment parameters, the model was calibrated by experience according to the related studies due to the lack of observed data (Qiu et al., 2012; Wang and Cui, 2011; $\mathrm{Xu}$ et al., 2008; Zhang et al., 2003). The optimum value of the calibrated sediment parameters is shown in Table 8. 


$$
-15677 \text { - }
$$

Table 8. Optimum value of calibrated sediment parameters for the SWAT model

\begin{tabular}{c|c|c|c|c|c|c|c}
\hline Name & USLE_C & USLE_P & USLE_K & CH_EROD & CH_COV & SPCON & SPEXP \\
\hline Value & 0.5 & 0.2 & 0.15 & 0.15 & 0.6 & 0.005 & 1.2 \\
\hline
\end{tabular}

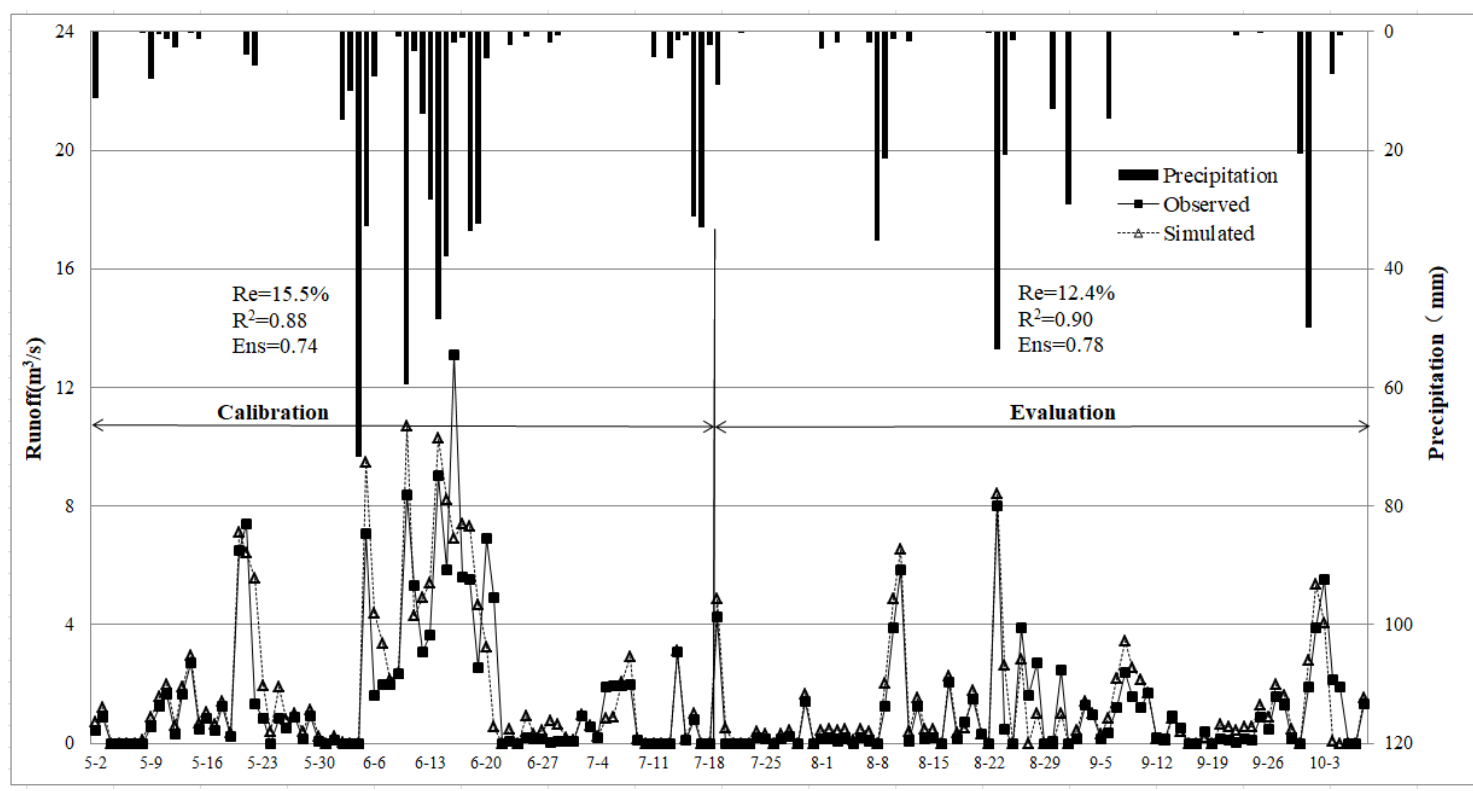

Figure 4. Comparisons between the observed and simulated daily runoff during the calibration and validation period

The SWAT model simulated value reflected the actual changes in the runoff yield, and the SWAT model could be used for runoff simulation in the study area. Hence, the distributed hydrological model of the study area based on the SWAT model was successfully constructed.

\section{Results}

\section{Runoff and sediment yield variations in response to precipitation}

\section{Statistical analysis of precipitation data}

In this study, the annual precipitation data of the study area during 1978-2010 were used for frequency calculation and the characteristic hydrological years were identified. The empirical frequency is calculated using the equation as follows:

$$
P=\frac{m}{n+1}
$$

where $P$ is the empirical frequency of the annual precipitation of a particular year, $m$ is the number in order from largest to smallest of the precipitation (Table 9), $n$ is the total number of annual precipitation data.

Table 9 shows the precipitation and the result of empirical frequency calculation. As shown in Table 9, the multi-year average precipitation was $1523.19 \mathrm{~mm}$. 


$$
-15678 \text { - }
$$

Table 9. Precipitation and the result of frequency calculation

\begin{tabular}{c|c|c|c|c|c|c|c}
\hline Year & $\begin{array}{c}\text { Precipitation } \\
(\mathbf{m m})\end{array}$ & No. & $\begin{array}{c}\text { Frequency } \\
(\mathbf{P}, \boldsymbol{\%})\end{array}$ & Year & $\begin{array}{c}\text { Precipitation } \\
(\mathbf{m m})\end{array}$ & No. & $\begin{array}{c}\text { Frequency } \\
(\mathbf{P}, \boldsymbol{\%})\end{array}$ \\
\hline 2010 & 2317 & 1 & 2.94 & 1997 & 1468.2 & 18 & 52.94 \\
1995 & 2296 & 2 & 5.88 & 2001 & 1459.9 & 19 & 55.88 \\
2002 & 2120.1 & 3 & 8.82 & 1992 & 1404.8 & 20 & 58.82 \\
2005 & 2063.5 & 4 & 11.76 & 1989 & 1400.3 & 21 & 61.76 \\
1999 & 1884.4 & 5 & 14.71 & 1987 & 1376.6 & 22 & 64.71 \\
2006 & 1856.4 & 6 & 17.65 & 2008 & 1362.9 & 23 & 67.65 \\
1993 & 1784.3 & 7 & 20.59 & 1996 & 1342.4 & 24 & 70.59 \\
1998 & 1748.1 & 8 & 23.53 & 1979 & 1295.3 & 25 & 73.53 \\
2003 & 1720.6 & 9 & 26.47 & 1985 & 1241.2 & 26 & 76.47 \\
2000 & 1680.1 & 10 & 29.41 & 1990 & 1228.2 & 27 & 79.41 \\
1983 & 1670.7 & 11 & 32.35 & 1988 & 1221.9 & 28 & 82.35 \\
1980 & 1583.7 & 12 & 35.29 & 1986 & 1211.8 & 29 & 85.29 \\
1994 & 1517.2 & 13 & 38.24 & 2009 & 1086.1 & 30 & 88.24 \\
1984 & 1501.2 & 14 & 41.18 & 2007 & 1045.3 & 31 & 91.18 \\
2004 & 1485 & 15 & 44.12 & 1978 & 986.9 & 32 & 94.12 \\
1981 & 1483.4 & 16 & 47.06 & 1991 & 940.9 & 33 & 97.06 \\
1982 & 1481 & 17 & 50.00 & Average & 1523.19 & Cv & 0.23 \\
\hline
\end{tabular}

The variation coefficient and ocular estimation method was used to draw theoretical frequency curve of the annual precipitation data, the best-fitted theoretical frequency curve was drawn when the coefficient of variation $(\mathrm{Cv})$ was 0.23 , as shown in Figure 5. The characteristic hydrological years were chosen with the frequency of 5\%, 20\%, 50\%, $70 \%$, and $95 \%$ according to the theoretical frequency curve. According to Table 1, the soil map and land-use map were compiled in 2009, so 2002 (8.82\%), 2006 (17.65\%), 2004 (44.12\%), 2008 (67.65\%), and 2009 (88.24\%) were chosen as the corresponding years, which are close to 2009 and will decrease the impact of land-use and soil change on simulation results in SWAT model.

\section{Analysis of runoff and sediment variation response to precipitation change}

At first, the annual yield of runoff and sediment of characteristic hydrological years was analyzed. The results are shown in Table 10 and Figure 6 . The runoff and sediment yields increased with an increase in precipitation. The correlation coefficient of runoff yield and precipitation was 0.94 , whereas that of the sediment yield and precipitation was 0.85 . Hence, a strong positive correlation was observed between the runoff yield and precipitation, as well as between sediment yield and precipitation.

Table 10. Precipitation and the result of frequency calculation

\begin{tabular}{c|c|c|c|c|c}
\hline Year & $\mathbf{2 0 0 2}$ & $\mathbf{2 0 0 6}$ & $\mathbf{2 0 0 4}$ & $\mathbf{2 0 0 8}$ & $\mathbf{2 0 0 9}$ \\
\hline P $(\%)$ & 5 & 20 & 50 & 70 & 95 \\
Precipitation $(\mathrm{mm})$ & 2120.1 & 1856.4 & 1485 & 1362.9 & 1086.1 \\
Runoff $\left(\mathrm{m}^{3} \mathrm{~s}^{-1}\right)$ & 1.90 & 1.76 & 1.22 & 1.28 & 1.09 \\
Sediment $\left(\mathrm{ta}^{-1}\right)$ & 438.02 & 490.47 & 291.04 & 267.93 & 207.93 \\
\hline
\end{tabular}




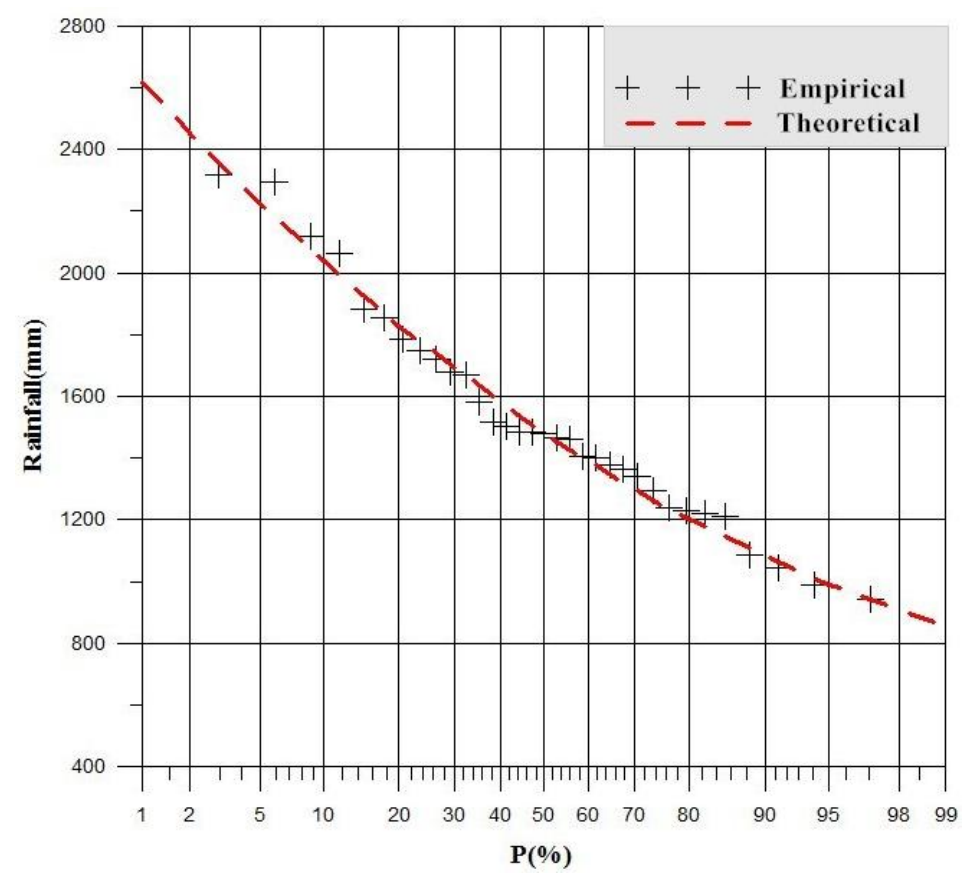

Figure 5. Theoretical frequency curve of precipitation
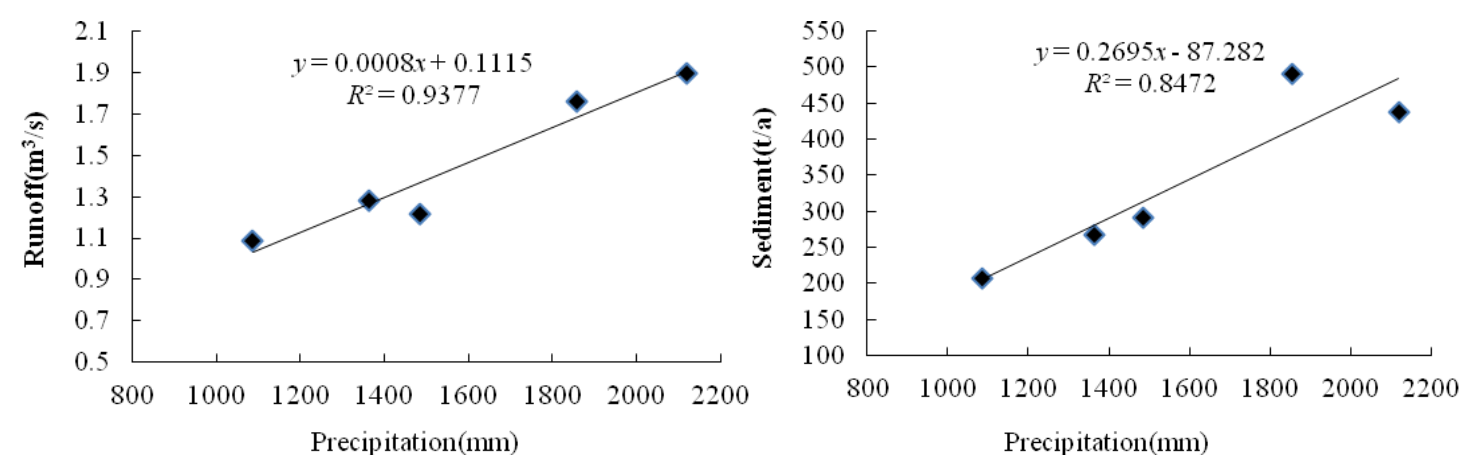

Figure 6. Correlation diagram of runoff and precipitation, as well as sediment and precipitation

Then, 2004 was chosen as the typical year $(\mathrm{P}=50 \%)$, and the monthly yield of runoff and sediment were simulated. The results are shown in Figure 7. The runoff and sediment had the same tendency of changes with precipitation variation.

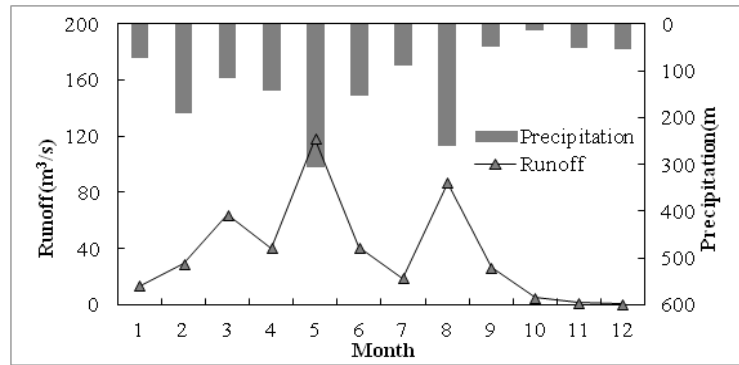

(a)

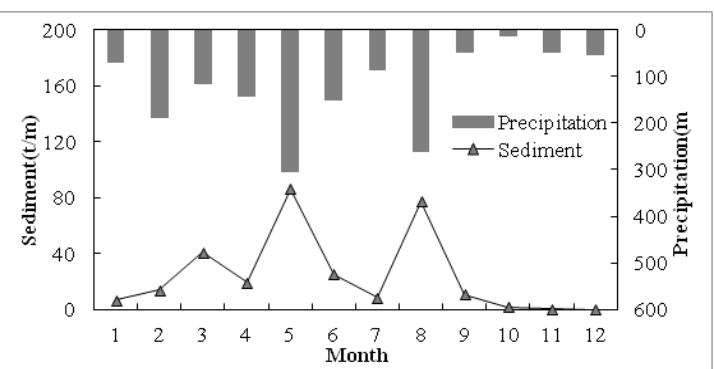

(b)

Figure 7. Monthly runoff and sediment variation response to precipitation changes 


\section{Runoff and sediment yield under different land use type}

During sub-basin calculation, the land-use area threshold setting method was used to reduce the calculation amount of SWAT model and the HRU amount of the study area. Therefore, the land-use type was readjusted to another type if the area percentage was less than the area threshold. In this study, $1 \%$ was used as the land-use area threshold. The changes in the land-use area before and after HRU calculation are shown in Table 11 .

Table 11. Land-use area changes before and after HRU calculation

\begin{tabular}{c|c|c|c|c}
\hline \multirow{2}{*}{ Type } & \multicolumn{2}{|c|}{ Before } & \multicolumn{2}{c}{ After } \\
\cline { 2 - 5 } & Area (ha) & Percentage (\%) & Area (ha) & Percentage (\%) \\
\hline AGRR (dry land) & 52.67 & 1.71 & 73.30 & 2.38 \\
RICE (paddy land) & 2441.67 & 79.27 & 2442.60 & 79.30 \\
URLD (rural residential land) & 188.20 & 6.11 & 186.40 & 6.05 \\
WATR (water area) & 389.03 & 12.63 & 377.90 & 12.27 \\
FRST (forest and grass land) & 7.39 & 0.24 & 0 & 0 \\
BARE (bare land) & 1.23 & 0.04 & 0 & 0 \\
\hline Total & 3080.20 & 100 & 3080.20 & 100 \\
\hline
\end{tabular}

Then, the per unit area yield of runoff and sediment of different land-use types in 2004 was calculated. The results are shown in Figure 8.

As illustrated in Figure $8 a$, the order of per unit area yield of total runoff from high to low was paddy land, rural residential land, dry land, and water area. Specially, the total yield from paddy land was much more than that from other land-use types in the study area. Likewise, the ground water runoff from paddy land was also much more than that from other land-use types in the study area. Further, the surface runoff yields from different land-use types were almost the same.

As illustrated in Figure $8 b$, the order of sediment yield from high to low was rural residential land, dry land, water area, and paddy land.

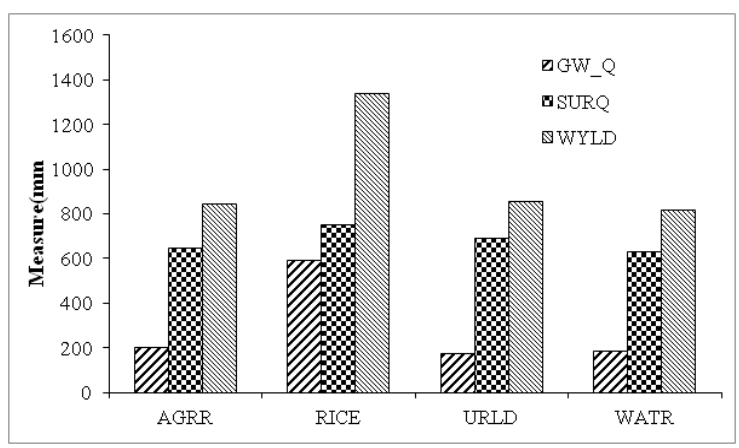

(a)

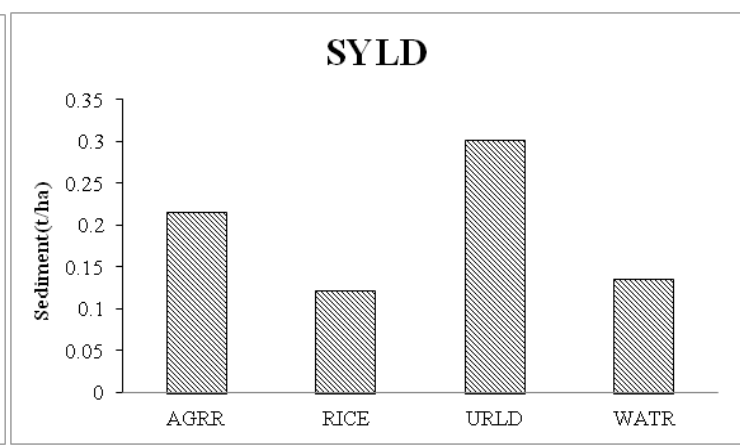

(b)

Figure 8. Runoff and sediment yield of per unit area from different land-use types in 2004. a Per unit area yield of runoff (GW_Q is groundwater, SURQ is surface runoff, WYLD is total runoff). $\boldsymbol{b}$ Per unit area yield of sediment (SYLD is total yield of sediment) 


\section{Discussion}

Based on the SWAT model with CMADS data, observed data from Jiangxi Irrigation Experimental Center, and field observation, the distributed hydrological model of the study area was constructed and the runoff and sediment yield variations under different precipitation and land-use conditions were simulated and analyzed.

For model calibration and evaluation, the observed runoff yield data were used to finish runoff parameter calibration. The sediment yield parameters were calibrated based on the results of other studies in different study areas due to the lack of observed data. For further study, the sediment simulation would be more accurate if the observed sediment data in the study area are used for model calibration.

At first, the observed annual precipitation data from 1978 to 2011 were used to finish frequency calculation and characteristic hydrological year identification. The runoff yield and sediment yield of characteristic hydrological years were simulated. A strong positive correlation was observed between the annual runoff yield and annual precipitation, as well as between sediment yield and precipitation, such results are also available from other studies (Li and Gao, 2015; Ruan et al., 2017; Zhu et al., 2015).

Then, 2004 was chosen as the typical year (50\%), and the monthly yield of runoff and sediment was simulated. Runoff and sediment had the same tendency of changes with precipitation variation. Specifically, a small spike for runoff, as well as for sediment, was observed in March with the decrease in precipitation, while a sharp decrease appeared in April with a relatively high increase in precipitation. That is to say, precipitation variation was not the only influencing factor for runoff and sediment changes. Several studies explored the influencing factors for runoff and sediment yield in different watersheds around the world (Jiang et al., 2008; Nguyen et al., 2017; Perry, 2015; Tong et al., 2018; Xiang et al., 2012; Alibuyog et al., 2009). Some other studies also indicated that the land-use type was one of the most important influencing factors for runoff and sediment yield variation (Gyamfi et al., 2016; Huang and Lo, 2015; Zhang et al., 2010).

In this study, the per unit area yields of runoff and sediment in 2004 of different land-use types were calculated.

The total runoff, surface runoff, and ground water runoff yield of different land-use types were analyzed. No significant difference was found in surface runoff yields from different land-use types. However, the underground runoff yields from different landuse types varied greatly. The ground water runoff from paddy land was also much more than that from other land-use types in the study area. This might be attributed to the fact that the paddy land is irrigated during the growing period of double-cropping rice, and the underground water maintains a relatively high level for a long time. Therefore, it is not comprehensive to only consider the surface runoff in the simulation of watershed runoff. The difference between surface runoff and subsurface runoff may increase, and hence the change and difference in runoff can be assessed from the time and space scale in the future studies.

The order of per unit area yield of total sediment from high to low was rural residential land, dry land, water area, and paddy land. The sediment yields from the rural residential land and dry land were much more than that from paddy land and water area. Thus, the rural residential land and dry land should be the major focus of soil erosion control and soil conservation. 


$$
-15682 \text { - }
$$

\section{Conclusions}

A distributed hydrological model was constructed in this study based on the SWAT model with CMADS data in the Fangxi Lake Watershed, a typical irrigation district in the Poyang Lake basin. The SWAT model was calibrated with observed runoff data. The results showed that the model was accurate enough for runoff and sediment yield simulation in the study area.

The runoff and sediment yield variations under different precipitation and land-use conditions were analyzed. The correlation coefficient of annual runoff yield and precipitation was 0.94 , whereas that of annual sediment yield and precipitation was 0.85 . Therefore, a positive correlation was observed between the annual runoff yield and precipitation, as well as between annual sediment yield and precipitation. When the monthly yield of runoff and sediment of typical year (2004) was simulated, the runoff and sediment yields had the same tendency of changes with precipitation variations. Then, the per unit area yield of runoff and sediment of different land-use types in 2004 was calculated. The order of per unit area yield of total runoff from high to low was paddy land, rural residential land, dry land, and water area. The order of per unit area yield of total sediment from high to low was rural residential land, dry land, water area, and paddy land. These findings figured out that the rural residential land and dry land are the main source of soil erosion.

However, several limitations in this study merit further research and investigation. The space distribution law of runoff and sediment should be taken into consideration in further studies. In addition, the transfer law of underground runoff and sediment in underground water under different rainfall and land-use conditions should be the focus of these studies.

Acknowledgments. The authors would like to express their sincere thanks to the State Key Laboratory of Water Resources and Hydropower Engineering Science, Wuhan University; the Nanchang County Agricultural Bureau Computer Network Information Center of Chinese Academy of Science; the China Meteorological Assimilation Driving Datasets for the SWAT Model; and the Jiangxi Irrigation Experimental Center for providing spatial and attribute data on Fangxi Lake Watershed. The authors also acknowledge the guidance from Professor Cui Yuanlai. They also thank the journal editors and anonymous reviewers for their useful comments and suggestions. This study was funded by the National Key R\&D Program of China (2017YFC150250304), the National Natural Science Foundation of China (51609009), the Fundamental Research Funds for Central Public Welfare Research Institutes (CKSF2016040/TB) and the Fundamental Research Funds for Central Public Welfare Research Institutes (CKSF2019410/TB).

Conflict of interests. The authors declare no conflict of interests.

\section{REFERENCES}

[1] Alibuyog, N. R., Ella, V. B., Reyes, M. R., Srinivasan, R., Heatwole, C., Dillaha, T., Gassman, P. W. (2009): Predicting the effects of land use change on runoff and sediment yield in Manupali River subwatersheds using the SWAT model. - International Agricultural Engineering Journal 18: 15-25.

[2] Arnold, J. G., Srinivasan, R., Muttiah, R. S., Allen, P. M. (1999): Continental scale simulation of the hydrologic balance 1. - JAWRA Journal of the American Water Resources Association 35: 1037-1051. 
[3] Bärlund, I., Kirkkala, T. (2008): Examining a model and assessing its performance in describing nutrient and sediment transport dynamics in a catchment in southwestern Finland. - Boreal Environ Res. 13: 195-207.

[4] Binh, P. D., Wu, C.-C., Hsieh, S.-C. (2011): Land use change effects on discharge and sediment yield of song cau catchment in northern Vietnam. - Journal of Environmental Science \& Engineering 5: 92-101.

[5] Chen, X., Xiao, W., Huang, Z., Zeng, L. (2016): Impact of spatial data on the accuracy of watershed hydrological simulation of SWAT model. - Science of Soil \& Water Conservation 2: 138-143.

[6] Daggupati, P., Shukla, R., Mekonnen, B., Rudra, R., Biswas, A., Goel, P. K., Prasher, S., Yang, W. (2018): Hydrological responses to various land use, soil and weather inputs in northern Lake Erie basin in Canada. - Water 10: 222.

[7] Dai, J. F., Cui, Y. L. (2009a): Distributed hydrological model for irrigation area based on SWAT I. Principle and method. - Journal of Hydraulic Engineering 40: 145-152.

[8] Dai, J. F., Cui, Y. L. (2009b): Distributed hydrological model for irrigation area based on SWAT II. Model application. - Journal of Hydraulic Engineering 40: 311-318.

[9] Dechmi, F., Burguete, J., Skhiri, A. (2012): SWAT application in intensive irrigation systems: model modification, calibration and validation. - Journal of Hydrology 470: 227-238.

[10] Di Luzio, M., Arnold, J. G., Srinivasan, R. (2005): Effect of GIS data quality on small watershed stream flow and sediment simulations. - Hydrological Processes: An International Journal 19: 629-650.

[11] Gassman, P. W., Reyes, M. R., Green, C. H., Arnold, J. G. (2007): The soil and water assessment tool: historical development, applications, and future research directions. Transactions of the ASABE 50(4): 1211-1250.

[12] Green, C. H., Griensven, A. V. (2008): Autocalibration in hydrologic modeling: Using SWAT2005 in small-scale watersheds. - Environmental Modelling \& Software 23: 422434.

[13] Gyamfi, C., Ndambuki, J. M., Salim, R. W. (2016): Simulation of sediment yield in a semi-arid river basin under changing land use: an integrated approach of hydrologic modelling and principal component analysis. - Sustainability 8: 1133.

[14] Hao, F. H., Cheng, H. G. (2006): Theory and application of non-point source pollution model. - China Environmental Science Press, Beijing.

[15] Himanshu, S. K., Pandey, A., Shrestha, P. (2017): Application of SWAT in an Indian river basin for modeling runoff, sediment and water balance. - Environmental Earth Sciences 76: 3 .

[16] Huang, T. C., Lo, K. F. A. (2015): Effects of land use change on sediment and water yields in Yang Ming Shan National Park, Taiwan. - Environments 2: 32-42.

[17] Jiang, X., Huang, C., Ruan, F. (2008): Impacts of land cover changes on runoff and sediment in the Cedar Creek Watershed, St. Joseph River, Indiana, United States. Journal of Mountain Science 5: 113-121.

[18] Koua, T. J., Jourda, J. P., Kouame, K. J., Anoh, K. A. (2013): Assessment of sediment and pollutants in Buyo Lake, Ivory Coast, using SWAT (soil and water assessment tool) model. - Journal of Chemistry and Chemical Engineering 7: 1054.

[19] Lam, Q. D., Schmalz, B., Fohrer, N. (2010): Modelling point and diffuse source pollution of nitrate in a rural lowland catchment using the SWAT model. - Agricultural Water Management 97: 317-325.

[20] Lee, S., Kim, S. U. (2017): Quantification of hydrological responses due to climate change and human activities over various time scales in South Korea. - Water 9: 34.

[21] Li, T., Gao, Y. (2015): Runoff and sediment yield variations in response to precipitation changes: a case study of Xichuan watershed in the Loess Plateau, China. - Water 7: 56385656. 
[22] Li, Y., Wang, K., Zhou, Z. (2014): Simulation of drainage and agricultural non-point source pollutions transport processes in paddy irrigation district in North-East China using SWAT. - Transactions of the Chinese Society of Agricultural Engineering 30: 4253.

[23] Li, Z., Sun, W., Wang, Z., Zhao, W., Sang, Y. (2013): Simulation of drainage and agricultural non-point source pollutions transportprocesses in paddy irrigation district in North-East China using SWAT. - J Hydroelectr Eng 77-82.

[24] Liu, J., Liu, S., Shangguan, D., Jingdong, X. U. (2017): Applicability evaluation of precipitation datasets from CMADS, ITPCAS and TRMM 3B42 in Yurungkax River basin. - Journal of North China University of Water Resources \& Electric Power 38: 2837.

[25] Liu, J., Shanguan, D., Liu, S., Ding, Y. (2018): Evaluation and hydrological simulation of CMADS and CFSR reanalysis datasets in the Qinghai-Tibet Plateau. - Water 10: 513.

[26] Loliyana, V. D., Patel, P. L. (2018): Performance evaluation and parameters sensitivity of a distributed hydrological model for a semi-arid catchment in India. - Journal of Earth System Science 127: 117.

[27] Me, W., Abell, J. M., Hamilton, D. P. (2015): Effects of hydrologic conditions on SWAT model performance and parameter sensitivity for a small, mixed land use catchment in New Zealand. - Hydrology and Earth System Sciences 19: 4127-4147.

[28] Meng, X., Wang, H. (2017): Significance of the China meteorological assimilation driving datasets for the SWAT Model (CMADS) of East Asia. - Water.

[29] Meng, X., Shi, C., Liu, S., Wang, H., Lei, X., Liu, Z., Xiaonan, J. I., Cai, S., Zhao, Q. (2016): CMADS datasets and its application in watershed hydrological simulation: a case study of the Heihe River basin. - Pearl River 37: 1-19.

[30] Meng, X., Long, A., Wu, Y., Yin, G., Wang, H., Ji, X. (2018): Simulation and spatiotemporal pattern of air temperature and precipitation in Eastern Central Asia using RegCM. - Scientific Reports 8: 3639.

[31] Min, F., Shibata, H. (2016): Water yield, nitrogen and sediment retentions in Northern Japan (Teshio river watershed): land use change scenario analysis. - Mitigation \& Adaptation Strategies for Global Change 21: 119-133.

[32] Nguyen, H. H., Recknagel, F., Meyer, W., Frizenschaf, J. (2017): Analysing the effects of forest cover and irrigation farm dams on streamflows of water-scarce catchments in South Australia through the SWAT model. - Water 9: 33.

[33] Nyeko, M. (2015): Hydrologic modelling of data scarce basin with SWAT model: capabilities and limitations. - Water Resources Management 29: 81-94.

[34] Panagopoulos, Y., Makropoulos, C., Baltas, E., Mimikou, M. (2011): SWAT parameterization for the identification of critical diffuse pollution source areas under data limitations. - Ecological Modelling 222: 3500-3512.

[35] Perry, K. A. (2015): Application of the SWAT hydrological model in a small, mountainous catchment in South Africa. - Mini-dissertation (MSc), University of Pretoria.

[36] Qiu, L., Zheng, F., Yin, R. (2012): SWAT-based runoff and sediment simulation in a small watershed, the loessial hilly-gullied region of China: capabilities and challenges. International Journal of Sediment Research 27: 226-234.

[37] Ruan, H., Zou, S., Yang, D., Wang, Y., Yin, Z., Lu, Z., Li, F., Xu, B. (2017): Runoff simulation by SWAT model using high-resolution gridded precipitation in the upper Heihe River Basin, Northeastern Tibetan Plateau. - Water 9: 866.

[38] Santhi, C., Srinivasan, R., Arnold, J. G., Williams, J. R. (2006): A modeling approach to evaluate the impacts of water quality management plans implemented in a watershed in Texas. - Environmental Modelling \& Software 21: 1141-1157.

[39] Tong, X. X., Cui, Y. L., Chen, M. Y., Hu, B., Xu, W. S. (2018): Simulation on change law of runoff, sediment and non-point source nitrogen and phosphorus discharge under 
different land uses based on SWAT model: a case study of Er hai Lake small watershed. IOP Conference Series: Earth and Environmental Science 153(5): 062062.

[40] Wang, H., Han, L., Wang, X., Zhu, Z. (2017): Research of runoff simulation in Xihe basin using SWAT model. - Journal of Liaoning Normal University 4: 558-562.

[41] Wang, J., Cui, Y. (2011): Modified SWAT for rice-based irrigation system and its assessment. - Transactions of the Chinese Society of Agricultural Engineering 27: 22-28.

[42] Wang, S., Xu, H. M., Gao, C. (2015): Water balance response of the climate change based on SWAT model in the Upper-Middle Reach of Huaihe River Basin. - Advances in Climate Change Research 11: 402-411.

[43] Weber, A., Fohrer, N., Möller, D. (2001): Long-term land use changes in a mesoscale watershed due to socio-economic factors - effects on landscape structures and functions. - Ecological modelling 140: 125-140.

[44] Xiang, L., Niu, J. Z., Xie, B. Y., Han, Y. N., Tan, J. P., Zhang, Y. H. (2012): Characteristics of runoff and sediment generation of forest vegetation on a hill slope by use of artificial rainfall apparatus. - Journal of Forestry Research 23: 419-424.

[45] Xu, Q. G., Xi, B. D., He, L. S., Wei, Z. M., Yao, B., Huo, S. L. (2008): Research on nonpoint pollution sources in Daning River watershed of the Three Georges Reservoir. Journal of Environmental Engineering 2: 299-303.

[46] Yang, J. J., Gao, X. H., Qi-Jiang, L. I., Chen, Q., Feng, S. C. (2013): SWAT model construction and uncertainty analysis on its parameters for the Huangshui River basin. Research of Soil \& Water Conservation 2: 82-93.

[47] Zettam, A., Taleb, A., Sauvage, S., Boithias, L., Belaidi, N., Sánchez-Pérez, J. M. (2017): Modelling hydrology and sediment transport in a semi-arid and anthropized catchment using the SWAT model: the case of the Tafna river (northwest Algeria). - Water 9: 216.

[48] Zhang, X. S., Hao, F. H., Yang, Z. F., Cheng, H. G., Beijing (2003): Runoff and sediment yield modeling in meso-scale watershed based on SWAT model. - Research of Soil \& Water Conservation 10: 38-42.

[49] Zhang, X., Wenhong, C., Qingchao, G., Sihong, W. (2010): Effects of landuse change on surface runoff and sediment yield at different watershed scales on the Loess Plateau. International Journal of Sediment Research 25: 283-293.

[50] Zhu, Q. D., Sun, J. H., Hua, G. F., Wang, J. H., Wang, H. (2015): Runoff characteristics and non-point source pollution analysis in the Taihu Lake Basin: a case study of the town of Xueyan, China. - Environmental Science and Pollution Research 22: 15029-15036. 